Click www.researchjournal.co.in/online/subdetail.html to purchase.

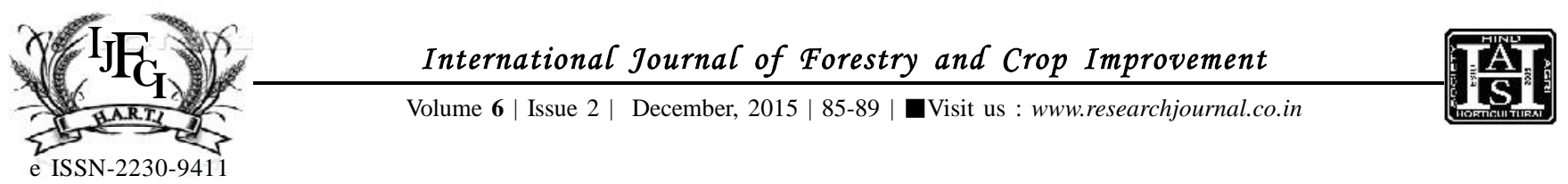

RESEARCH ARTICLE

DOI: $10.15740 / \mathrm{HAS} / \mathrm{IJFCI} / 6.2 / 85-89$

\title{
Effects of row ratios of grass fodder cowpea mixtures on the yield and quality of forages
}

\author{
M.R. ANITA, S. LAKSHMI AND T. SAJITHARANI
}

\begin{abstract}
A field experiment was conducted at the Instructional Farm, College of Agriculture, Vellayani, Thiruvananthapuram during January 2012 to March 2014 to find out the effect of grass-fodder cowpea mixtures and row ratio on the growth characters of fodder grasses and fodder cowpea in open and in partial shade. The experiments were laid out in RBD with three replications, comprising of two grasses $\left[\mathrm{G}_{1}-\right.$ Hybrid napier (Suguna), $\mathrm{G}_{2}$ - Guinea grass (Harithasree)], two fodder cowpea varieties $\left(\mathrm{V}_{1}\right.$ - COFC8 (open and shade), $\mathrm{V}_{2}$ - UPC-622 (open), UPC-618 (shade) and three grass legume row ratios $\left(\mathrm{R}_{1}-1: 1, \mathrm{R}_{2}-1: 2, \mathrm{R}_{3}-1: 3\right.$ ). The results indicated the superiority of the grass legume mixture of hybrid napier cv. SUGUNA with both the fodder cowpea varieties in the grass legume row ratio of 1:3 with respect to yield and quality of fodder crops in open and shaded experiments.
\end{abstract}

KEY WORDS : Hybrid napier grass, Guinea grass, Crude protein, Crude fibre, Row ratio

HOW TO CITE THIS ARTICLE : Anita, M.R., Lakshmi, S. and Rani, T. Sajitha (2015). Effects of row ratios of grass fodder cowpea mixtures on the yield and quality of forages. Internat. J. Forestry \& Crop Improv., 6 (2) : 85-89.

ArTiCle ChroniCAL : Received : 14.07.2015; Revised : 01.11.2015; Accepted : 15.11.2015 